\title{
Peripheral neuropathy in COVID-19 is due to immune-mechanisms, pre-existing risk factors, anti-viral drugs, or bedding in the Intensive Care Unit
}

\author{
Neuropatia periférica na COVID-19 com mecanismos immunológicos, fatores de risco \\ preexistentes, medicamentos antivirais e compressão dos nervos periféricos nos leitos da \\ Unidade de Terapia Intensiva \\ Josef FINSTERER', Fulvio Alexandre SCORZA², Carla Alessandra SCORZA², Ana Claudia FIORIN/3,4
}

\begin{abstract}
Background: This mini-review aims to summarize and discuss previous and recent advances in the clinical presentation, pathophysiology, diagnosis, treatment, and outcome of SARS-CoV-2-associated peripheral neuropathies. Methods: Literature review. Results: Altogether, 105 articles about SARS-CoV-2-associated neuropathy describing 261 patients were retrieved. Peripheral neuropathy in patients with COVID-19 is frequent and predominantly due to immune mechanisms or neurotoxic side effects of drugs used to treat the symptoms of COVID-19 and, to a lesser extent, due to the compression of peripheral nerves resulting from prolonged bedding in the Intensive Care Unit (ICU) and pre-existing risk factors such as diabetes. SARS-CoV-2 does not cause viral neuropathy. Neurotoxic drugs such as daptomycin, linezolid, lopinavir, ritonavir, hydro-chloroquine, cisatracurium, clindamycin, and glucocorticoids should be administered with caution and patients should be appropriately bedded in the ICU to prevent SARS-CoV-2-associated neuropathy. Patients with Guillain-Barré syndrome (GBS) benefit from immunoglobulins, plasma exchange, and steroids. Conclusions: Neuropathies of peripheral nerves in patients with COVID-19 are frequent and mostly result from immune mechanisms or neurotoxic side effects of drugs used to treat the symptoms of COVID-19 and, to a lesser extent, from the compression of peripheral nerves due to prolonged bedding on the ICU. SARS-CoV-2 does not cause infectious neuropathy.
\end{abstract}

Keywords: Guillain-Barre Syndrome; Polyneuropathies; Drug-Related Side Effects and Adverse Reactions; Mononeuritis Multiplex; SARS-COV-2.

\begin{abstract}
RESUMO
Introdução: A presente minirrevisão tem como objetivo resumir e discutir os avanços dos aspectos clínicos, fisiopatológicos, de diagnóstico, tratamento e evolução das neuropatias dos nervos periféricos associadas à COVID-19. Métodos: Revisão da literatura. Resultados: Foram avaliados 105 artigos sobre neuropatia associada à COVID-19. Nesses estudos, 261 pacientes apresentaram boa evolução. As neuropatias dos nervos periféricos em pacientes com COVID-19 são frequentes e se devem, principalmente, aos mecanismos immunológicos ou efeitos colaterais neurotóxicos dos medicamentos utilizados para o tratamento da COVID-19, a fatores de risco pré-existentes, como diabetes e, em menor parte, à compressão dos nervos periféricos nos leitos da UTI. A COVID-19 não causa neuropatia viral. Os medicamentos neurotóxicos, como daptomicina, linezolida, lopinavir, ritonavir, hidro-cloroquina, cisatracúrio, clindamicina e glicocorticoides devem ser administrados com cautela, e os pacientes deve ser adequadamente admitidos nos leitos da UTI para prevenir o desenvolvimento de neuropatia associada à COVID-19. Pacientes com síndrome de Guillain-Barré (GBS) se beneficiam de imunoglobulinas, plasmaférese e esteroides. Conclusões: As neuropatias dos nervos periféricos em pacientes com COVID-19 são raras e predominantemente devidas aos efeitos colaterais neurotóxicos das mecanismos immunológicos ou drogas utilizadas para o tratamento de COVID-19 e, em menor parte, devido à compressão dos nervos periféricos nos leitos da UTI. A COVID-19 não causa neuropatia infeciosa.
\end{abstract}

Palavras-chave: Síndrome de Guillain-Barré; Polineuropatias; Efeitos Colaterais e Reações Adversas Relacionados a Medicamentos; Mononeuropatias; SARS-CoV-2.

\footnotetext{
${ }^{1}$ Klinik Landstrasse, Messerli Institute, Vienna, Austria.

${ }^{2}$ Universidade Federal de São Paulo, Escola Paulista de Medicina, Disciplina de Neurociência, São Paulo SP, Brazil.

${ }^{3}$ Pontifícia Universidade Católica de São Paulo, Programa de Pós-Graduação em Fonoaudiologia, São Paulo SP, Brazil.

¿Universidade Federal de São Paulo, Escola Paulista de Medicina, Departamento de Fonoaudiologia, São Paulo SP, Brazil.

JF (DD https://orcid.org/0000-0003-2839-7305; FAS (D) https://orcid.org/0000-0002-0694-8674; CAS (D) https://orcid.org/0000-0001-7810-4748;

ACF (ID) https://orcid.org/0000-0003-2989-2308
}

Correspondence: Josef Finsterer; Email: fifigs1@yahoo.de

Conflict of interests: There is no conflict of interests to declare.

Authors' contribution: JF: design, literature search, discussion, first draft, critical comments. FS, CS, and AF: literature search, discussion, critical comments, final approval

Received on January 26, 2021; Received in its final form on February 11, 2021; Accepted on March 21, 2021.

\section{(cc) BY}




\section{INTRODUCTION}

Infection with SARS-CoV-2 (COVID-19) causes not only pneumonia, but also neurological, cardiac, renal, hepatic, pancreatic, and gastrointestinal compromise ${ }^{1,2}$. Neurological involvement following the infection has been increasingly acknowledged and includes impairment not only of the central nervous system (CNS), but also of the peripheral nervous system (PNS) ${ }^{3}$, SARS-CoV-2-associated PNS disease includes rhabdomyolysis, myopathy, myositis, myasthenia, myasthenic syndrome, polyradiculitis with or without involvement of cranial nerves, and peripheral neuropathy. This mini-review aims to summarize and discuss previous and recent advances in the clinical presentation, pathophysiology, diagnosis, treatment, and outcome of SARS-CoV-2-associated peripheral neuropathy.

\section{METHODS}

A literature review after a search on the database PubMed using the terms "neuropathy", "peripheral nerves", "polyneuropathy”, "polyardiculitis", "Guillain-Barré syndrome”, "polyradiculoneuritis", and "nerves" along with "SARS-CoV-2", "COVID-19", and "coronavirus". Additionally, reference lists were checked for further articles meeting the search criteria. Articles published in languages other than English, French, Spanish, Italian, or German were excluded.

\section{RESULTS}

Altogether, 105 articles about SARS-CoV-2-associated neuropathy describing 220 patients with Guillain-Barré syndrome (GBS) ${ }^{4}$ and 41 patients with non-GBS neuropathy were retrieved $\mathrm{d}^{5,6,7,8,9,10,11,12,13,14}$. The age of these 261 patients, reported in 244 of them, ranged from 8 to 94 years. In total, 253 patients had their gender reported, 179 being males and 74 being females. Latency between the onset of viral infection and onset of neuropathy was reported in 168 patients and ranged from -10 to 90 days. Neuropathy was classified in 257 patients. Two-hundred and twenty patients were diagnosed as GBS, four were diagnosed with critical illness neuropathy ${ }^{6}$, eleven with mononeuritis multiplex ${ }^{7}$, sixteen with plexopathy ${ }^{10}$, four with isolated sensory neuropathy ${ }^{12}$, and two with meralgia paresthetica ${ }^{9}$. Risk factors for neuropathy identified were pre-existing diabetes, obesity, drug use, and prolonged stay in the intensive care unit (ICU). Drugs known to cause neuropathy and given to patients included daptomycin $^{15}$, linezolid ${ }^{16}$, lopinavir ${ }^{17}$, ritonavir ${ }^{18}$, hydro-chloroquine ${ }^{19}$, cisatracurium $^{20}$, clindamycin ${ }^{21}$, tocilizumab ${ }^{22}$, and glucocorticoids ${ }^{23,24}$. Compression neuropathy was diagnosed in 18 cases $^{9,10,14}$. Nerve conduction studies (NCSs) showed axonal lesion in four patients ${ }^{6}$ and plexopathy in one patient ${ }^{10}$.
GBS subtypes identified were acute inflammatory demyelinating neuropathy (AIDP) in 118 patients, acute motor axonal neuropathy (AMAN) in 13 patients, acute motor and sensory axonal neuropathy (AMSAN) in 11 patients, MillerFisher syndrome in 7 patients, polyneuritis cranialis (PNC) in 2 patients, and the pharyngeal, cervical, and brachial (PCB) variant in 1 patient. Treatment of non-GBS neuropathy was reported in three cases and included steroids, intravenous immunoglobulins (IVIG), gabapentin (GBT), and capsaicin (Table 1). Therapy of GBS comprised IVIG, plasma exchange, steroids, or artificial ventilation.

The four non-GBS neuropathy patients with diabetes but without clinical neuropathy reported by Odriozola et al. did not undergo NCSs, but the sensory testing indicated development of sensory neuropathy during the SARS-CoV-2 infection $^{12}$. Since all four patients had diabetes and received neurotoxic drugs during hospitalisation, it is conceivable that both the infection and the neurotoxic drugs turned a previously subclinical neuropathy into a symptomatic neuropathy. Whether these patients also had subclinical motor involvement remains speculative. In the study by Garcia-Monco et al. on 35 patients with neurological presentation at onset of the SARS-CoV-2 infection, one presented with peripheral neuropathy ${ }^{13}$. Unfortunately, no further details about this patient were provided. A disadvantage of the study of 15 patients with brachial plexopathy conducted by Miller et al. is that the latency between onset of COVID-19 and onset of neuropathy, treatment, and outcome were not provided and that no NCSs had been carried out ${ }^{14}$. In the case reported by Faquihi et al., weakness of lower limbs had developed already prior to application of lopinavir/ritonavir, ribavirin, interferon beta$1 \mathrm{~b}$, broad spectrum antibiotics, vasopressors, and hydrocortisone ${ }^{8}$. Though this case is described as peripheral neuropathy, initial NCSs only revealed prolonged distal latencies with normal amplitudes, nerve conduction velocities, and F-wave latencies and follow-up NCSs were described as normal ${ }^{8}$. Thus, the diagnosis of "neuropathy" remains questionable.

\section{DISCUSSION}

This min-review shows that neuropathy of peripheral nerves, including polyradiculitis, is frequent in COVID-19 patients. The most common causes of SARS-CoV-2-associated peripheral neuropathy include GBS, drugs used to treat symptoms of COVID-19, pre-existing diabetes, and compression neuropathies due to prone bedding in the ICU. Whether diabetes or prolonged ICU stay caused neuropathy in the 13 patients with pre-existing diabetes was not differentiated in the appropriate papers. Few studies have been conducted to assess the prevalence of peripheral neuropathy caused by SARS-CoV-2 infection. In a study carried out in Bergamo on 1,760 COVID-19 patients, 9 patients developed critical illness neuropathy and 3 had peripheral neuropathy ${ }^{25}$. 
Table 1. List of patients with SARS-CoV-2-associated neuropathy of peripheral nerves published until the end of December 2020.

\begin{tabular}{|c|c|c|c|c|c|c|c|c|}
\hline Age & Sex & LOCON & Symptoms/signs & RF for neuropathy ${ }^{\wedge}$ & NCS & Therapy & Outcome & Reference \\
\hline 40 & $f$ & $28 d$ & Pain, numbness, weakness & $\mathrm{nr}$ & $\mathrm{nr}$ & $\begin{array}{l}\text { Steroids, } \\
\text { IVIG, GBT }\end{array}$ & PR & Bureau et al. ${ }^{5}$ \\
\hline 75 & m & $\mathrm{nr}$ & General distal weakness, & Daptomycin, linezolid & Axonal & $\mathrm{nr}$ & $\mathrm{nr}$ & $\begin{array}{c}\text { Cabañes- } \\
\text { Martínez et al. }{ }^{6}\end{array}$ \\
\hline 61 & $\mathrm{~m}$ & $\mathrm{nr}$ & Generalized weakness, & Cisatracurium, 21d ICU, & Axonal & $\mathrm{nr}$ & $\mathrm{nr}$ & $\begin{array}{c}\text { Cabañes- } \\
\text { Martínez et al. }{ }^{6}\end{array}$ \\
\hline 66 & $\mathrm{~m}$ & $\mathrm{nr}$ & Generalized weakness, & Cisatracurium, lopinavir & Axonal & $\mathrm{nr}$ & $\mathrm{nr}$ & $\begin{array}{c}\text { Cabañes- } \\
\text { Martínez et al. }{ }^{6}\end{array}$ \\
\hline 63 & m & $\mathrm{nr}$ & Generalized weakness & Clindamycin, linezolid, & Axonal & $\mathrm{nr}$ & $\mathrm{nr}$ & $\begin{array}{l}\text { Cabañes- } \\
\text { Martínez et al. }{ }^{6}\end{array}$ \\
\hline ÆE58 & m8 & $\mathrm{nr}$ & Mononeuritis multiplex & $\operatorname{MV}(16-73 d)$ & $\mathrm{nr}$ & $\mathrm{nr}$ & $\mathrm{nr}$ & $\begin{array}{l}\text { Needham } \\
\text { et al.? }[n=11]\end{array}$ \\
\hline 44 & m & $12 d$ & Lower limb weakness & $\mathrm{nr}$ & $\mathrm{dL}$ & TPE & $\mathrm{CR}$ & Faqihi et al. ${ }^{8}$ \\
\hline 53 & $\mathrm{~m}$ & $\mathrm{nr}$ & Meralgia paresthetica & Diabetes, MV (11d) & $\mathrm{nr}$ & None & $\mathrm{CR}$ & $\begin{array}{c}\text { Bellinghausen } \\
\text { et al. }{ }^{9}\end{array}$ \\
\hline 57 & $\mathrm{~m}$ & $\mathrm{nr}$ & Meralgia paresthetica & $\mathrm{MV}(10 \mathrm{~d})$ & $\mathrm{nr}$ & Capsaicin & CR & $\begin{array}{c}\text { Bellinghausen } \\
\text { et al. }{ }^{9}\end{array}$ \\
\hline 69 & m & $\mathrm{nr}$ & Right arm weakness, & Lopinavir, ritonavir, & Plexus & $\mathrm{nr}$ & PR & $\begin{array}{l}\text { Sánchez- } \\
\text { Soblechero } \\
\text { et al. }{ }^{10}\end{array}$ \\
\hline 69 & m & Od & Lower limb weakness & Diabetes & $\mathrm{nr}$ & $\mathrm{nr}$ & PR & $\begin{array}{l}\text { Abdelnour } \\
\text { et al.11 }\end{array}$ \\
\hline 57 & m & $\mathrm{nr}$ & Sensory disturbances & $\begin{array}{c}\text { Diabetes, psoriasis, } \\
\text { steroids, lopinavir, } \\
\text { ritonavir, ICU chloroquine, } \\
\text { tocilizumab }\end{array}$ & $\mathrm{nr}$ & $\mathrm{nr}$ & PR & $\begin{array}{l}\text { Odriozola } \\
\text { et al.12 }\end{array}$ \\
\hline 68 & $\mathrm{~m}$ & $\mathrm{nr}$ & Sensory disturbances & $\begin{array}{l}\text { Diabetes, ICU, lopinavir, } \\
\text { ritonavir, chloroquine, } \\
\text { steroids, tocilizumab }\end{array}$ & $\mathrm{nr}$ & $\mathrm{nr}$ & PR & $\begin{array}{l}\text { Odriozola } \\
\text { et al.12 }\end{array}$ \\
\hline 73 & $\mathrm{~m}$ & $\mathrm{nr}$ & Sensory disturbances & $\begin{array}{l}\text { Diabetes, lopinavir, } \\
\text { chloroquine, steroids, } \\
\text { tocilizumab }\end{array}$ & & & & \\
\hline $\mathrm{nr}$ & $\mathrm{nr}$ & $\mathrm{nr}$ & Peripheral neuropathy & $\mathrm{nr}$ & $\mathrm{nr}$ & $\mathrm{nr}$ & $\mathrm{nr}$ & $\begin{array}{c}\text { García-Moncó } \\
\text { et al. } .^{13}\end{array}$ \\
\hline 60 & $\mathrm{~m}$ & $\mathrm{nr}$ & Brachial plexopathy & Diabetes, ICU & $\mathrm{nr}$ & $\mathrm{nr}$ & $\mathrm{nr}$ & Miller et al..$^{14}$ \\
\hline 41 & $f$ & $\mathrm{nr}$ & Brachial plexopathy & Diabetes, obesity, ICU & $\mathrm{nr}$ & $\mathrm{nr}$ & $\mathrm{nr}$ & Miller et al..$^{14}$ \\
\hline 60 & $\mathrm{~m}$ & $\mathrm{nr}$ & Brachial plexopathy & Diabetes, obesity, ICU & $\mathrm{nr}$ & $\mathrm{nr}$ & $\mathrm{nr}$ & Miller et al. ${ }^{14}$ \\
\hline 61 & $\mathrm{~m}$ & $\mathrm{nr}$ & Brachial plexopathy & Diabetes, ICU & $\mathrm{nr}$ & $\mathrm{nr}$ & $\mathrm{nr}$ & Miller et al. ${ }^{14}$ \\
\hline 42 & $\mathrm{~m}$ & $\mathrm{nr}$ & Brachial plexopathy & Obesity, ICU & $\mathrm{nr}$ & $\mathrm{nr}$ & $\mathrm{nr}$ & Miller et al. ${ }^{14}$ \\
\hline 69 & $\mathrm{~m}$ & $\mathrm{nr}$ & Brachial plexopathy & $\mathrm{ICU}$ & $\mathrm{nr}$ & $\mathrm{nr}$ & $\mathrm{nr}$ & Miller et al. ${ }^{14}$ \\
\hline 50 & $\mathrm{~m}$ & $\mathrm{nr}$ & Brachial plexopathy & Obesity, ICU & $\mathrm{nr}$ & $\mathrm{nr}$ & $\mathrm{nr}$ & Miller et al. ${ }^{14}$ \\
\hline 59 & $f$ & $\mathrm{nr}$ & Brachial plexopathy & Diabetes, obesity, ICU & $\mathrm{nr}$ & $\mathrm{nr}$ & $\mathrm{nr}$ & Miller et al..$^{14}$ \\
\hline 55 & $\mathrm{~m}$ & $\mathrm{nr}$ & Brachial plexopathy & Obesity, ICU & $\mathrm{nr}$ & $\mathrm{nr}$ & $\mathrm{nr}$ & Miller et al. ${ }^{14}$ \\
\hline 60 & $\mathrm{~m}$ & $\mathrm{nr}$ & Brachial plexopathy & Obesity, ICU & $\mathrm{nr}$ & $\mathrm{nr}$ & $\mathrm{nr}$ & Miller et al..$^{14}$ \\
\hline 41 & $\mathrm{~m}$ & $\mathrm{nr}$ & Brachial plexopathy & Diabetes, ICU & $\mathrm{nr}$ & $\mathrm{nr}$ & $\mathrm{nr}$ & Miller et al..$^{14}$ \\
\hline 57 & $\mathrm{~m}$ & $\mathrm{nr}$ & Brachial plexopathy & $\mathrm{ICU}$ & $\mathrm{nr}$ & $\mathrm{nr}$ & $\mathrm{nr}$ & Miller et al..$^{14}$ \\
\hline 59 & $\mathrm{~m}$ & $\mathrm{nr}$ & Brachial plexopathy & $\mathrm{ICU}$ & $\mathrm{nr}$ & $\mathrm{nr}$ & $\mathrm{nr}$ & Miller et al. ${ }^{14}$ \\
\hline 39 & m & $\mathrm{nr}$ & Brachial plexopathy & Diabetes, obesity, ICU & $\mathrm{nr}$ & $\mathrm{nr}$ & $\mathrm{nr}$ & Miller et al. ${ }^{14}$ \\
\hline 64 & $\mathrm{~m}$ & $\mathrm{nr}$ & Brachial plexopathy & $\mathrm{ICU}$ & $\mathrm{nr}$ & $\mathrm{nr}$ & $\mathrm{nr}$ & Miller et al..$^{14}$ \\
\hline $8-94$ & $74 f$ & $-10-90$ & GBS & Various & $\begin{array}{l}\text { Variable, } \\
\text { according } \\
\text { to GBS } \\
\text { subtype }\end{array}$ & Variable & Variable & $\begin{array}{l}\text { Finsterer and } \\
\text { Scorza }{ }^{4}[\mathrm{n}=220]\end{array}$ \\
\hline
\end{tabular}

CR: complete recovery; dL: distal latency; GBT: gabapentin; IVIG: intravenous immunoglobulins; LOCON: latency between onset of COVID-19 and onset of neuropathy; MV: mechanical ventilation; NCS: nerve conduction studies; nr: not reported; PR: partial recovery; TPE: therapeutic plasma exchange. 
Unfortunately, no further details about these patients were provided. The estimated incidence of GBS between $3 / 2020$ and $4 / 2020$ was $2.43 / 100000 / y$ in Northern Italy ${ }^{26}$. Patients requiring prone position for treatment of acute respiratory distress syndrome (ARDS) in the ICU are predisposed to develop compression neuropathy. In a retrospective study of 83 patients with ARDS due to SARS-CoV-2, 12 patients (14.5\%) developed peripheral nerve injury ${ }^{27}$. One patient in prone position for mechanical ventilation developed unilateral plexopathy. In 15 other patients, brachial plexopathy evolved during ICU stay ${ }^{14}$. Among the 11 patients with mononeuritis multiplex reported by Needham et al. ${ }^{7}$, the etiology of neuropathy remained elusive. Though the authors speculated that distribution of sensory or motor deficits suggested vasculitis, none of the 11 patients had undergone nerve biopsy to confirm or exclude this diagnosis. Concerning GBS, this review shows that SARS-CoV-2-associated GBS is not due to a direct attack of the virus, but rather due to an immunological reaction to the virus.

In none of the patients included in this review were there any indications for viral neuropathy. These findings suggest that SARS-CoV-2 does not damage peripheral nerves by a direct attack but rather by secondary immune mechanisms. Pre-existing damage of peripheral nerves, side effects of drugs used to treat manifestations of COVID-19, and positioning of patients seem to be the most relevant causes of SARS-CoV-2-associated non-GBS related peripheral neuropathy. Accordingly, it is crucial not only to avoid the use of neurotoxic drugs, but also to sufficiently treat pre-existing diabetes, and to avoid bedding of the patients during mechanical ventilation in a position that can favor the development of compression neuropathy. This may help to prevent the development of peripheral neuropathy during SARS-CoV-2 infection.

Peripheral neuropathies in patients with COVID-19 are frequent and mostly result from immune mechanisms and neurotoxic side effects of drugs applied to treat COVID-19 and, to a lesser extent, from the compression of peripheral nerves after prolonged bedding on the ICU. SARS-CoV- 2 does not cause viral neuropathy. Neurotoxic drugs such as daptomycin, linezolid, lopinavir, ritonavir, hydro-chloroquine, cisatracurium, clindamycine, and glucocorticoids should be used with caution and patients in the ICU should be appropriately bedded to prevent SARS-CoV-2-associated neuropathy.

\section{References}

1. Bal A, Agrawal R, Vaideeswar P, Arava S, Jain A. COVID-19: An upto-date review - from morphology to pathogenesis. Indian J Pathol Microbiol. 2020 Jul-Sep;63(3):358-66. https://doi.org/10.4103/IJPM IJPM_779_20

2. da Rosa Mesquita R, Francelino Silva Junior LC, Santos Santana FM, Farias de Oliveira T, Campos Alcântara R, Monteiro Arnozo G, et al. Clinical manifestations of COVID-19 in the general population: systematic review. Wien Klin Wochenschr. 2020 Nov:1-6. https://doi. org/10.1007/s00508-020-01760-4.

3. Maramattom BV, Bhattacharjee S. Neurological Complications with COVID-19: A Contemporaneous Review. Ann Indian Acad Neurol. 2020 Jul-Aug;23(4):468-76. https://doi.org/10.4103/aian. AIAN_596_20

4. Finsterer J, Scorza FA. Guillain-Barre syndrome in 220 patients with COVID-19. Egypt J Neurol Psychiatr Neurosurg. 2021;57(1):55. https://doi.org/10.1186/s41983-021-00310-7

5. Bureau BL, Obeidat A, Dhariwal MS, Jha P. Peripheral Neuropathy as a Complication of SARS-Cov-2. Cureus. 2020 Nov;12(11):e11452. https://doi.org/10.7759/cureus.11452

6. Cabañes-Martínez L, Villadóniga M, González-Rodríguez L, Araque L, Díaz-Cid A, Ruz-Caracuel I, et al. Neuromuscular involvement in COVID-19 critically ill patients. Clin Neurophysiol. 2020 Dec;131(12):2809-16. https://doi.org/10.1016/j.clinph.2020.09.017

7. Needham E, Newcombe V, Michell A, Thornton R, Grainger A, Anwar F, et al. Mononeuritis multiplex: an unexpectedly frequent feature of severe COVID-19.J Neurol. 2020 Nov:1-5. https://doi.org/10.1007/ s00415-020-10321-8

8. Faqihi F, Alharthy A, Memish ZA, Kutsogiannis DJ, Brindley PG, Karakitsos D. Peripheral neuropathy in severe COVID-19 resolved with therapeutic plasma exchange. Clin Case Rep. 2020 Oct;8(12):3234-9. https://doi.org/10.1002/ccr3.3397

9. Bellinghausen AL, LaBuzetta JN, Chu F, Novelli F, Rodelo AR, Owens RL. Lessons from an ICU recovery clinic: two cases of meralgia paresthetica after prone positioning to treat COVID-19associated ARDS and modification of unit practices. Crit Care. 2020 Sep;24(1):580. https://doi.org/10.1186/s13054-020-03289-4

10. Sánchez-Soblechero A, García CA, Sáez Ansotegui A, FernándezLorente J, Catalina-Álvarez I, Grandas F, et al. Upper trunk brachial plexopathy as a consequence of prone positioning due to SARSCoV-2 acute respiratory distress syndrome. Muscle Nerve. 2020 Nov;62(5):E76-E78. https://doi.org/10.1002/mus.27055

11. Abdelnour L, Eltahir Abdalla M, Babiker S. COVID 19 infection presenting as motor peripheral neuropathy. J Formos Med Assoc. 2020 Jun;119(6):1119-20. https://doi.org/10.1016/j.jfma.2020.04.024

12. Odriozola A, Ortega L, Martinez L, Odriozola S, Torrens A, Corroleu $D$, et al. Widespread sensory neuropathy in diabetic patients hospitalized with severe COVID-19 infection. Diabetes Res Clin Pract. 2020 Dec:108631. https://doi.org/10.1016/j.diabres.2020.108631

13. García-Moncó JC, Cabrera-Muras A, Collía-Fernández A, ErburuIriarte M, Rodrigo-Armenteros P, Oyarzun-Irazu I, et al. Neurological reasons for consultation and hospitalization during the COVID-19 pandemic. Neurol Sci. 2020 Nov;41(11):3031-8. https://doi. org/10.1007/s10072-020-04714-W.

14. Miller C, O'Sullivan J, Jeffrey J, Power D. Brachial plexus neuropathies during the COVID-19 pandemic: a retrospective case series of 15 patients in critical care. Phys Ther. 2021 Jan;101(1):pzaa191. https:// doi.org/10.1093/ptj/pzaa191

15. Kushlaf HA. Emerging toxic neuropathies and myopathies. Neurol Clin. 2011 Aug;29(3):679-87. https://doi.org/10.1016/j. ncl.2011.05.009

16. Pilania RK, Arora A, Agarwal A, Jindal AK, Aggarwal K, Krishnan G, et al. Linezolid-induced mitochondrial toxicity presenting as retinal nerve fiber layer microcysts and optic and peripheral neuropathy in a patient with chronic granulomatous disease. Retin Cases Brief Rep. 2021 May;15(3):224-9. https://doi.org/10.1097/ ICB.0000000000000777 
Khanlou H, Valdes-Sueiras M, Farthing C. Peripheral neuropathy induced by lopinavir-saquinavir-ritonavir combination therapy in an HIV-infected patient.J Int Assoc Physicians AIDS Care (Chic). 2007 Sep;6(3):155. https://doi.org/10.1177/1545109707302756.

18. Lorber M. A case of possible darunavir/ritonavir-induced peripheral neuropathy: case description and review of the literature. J Int Assoc Provid AIDS Care. 2013 May-Jun;12(3):162-5. https://doi. org/10.1177/2325957412471993

19. Becerra-Cuñat JL, Coll-Cantí J, Gelpí-Mantius E, Ferrer-AvellíX, LozanoSánchez M, Millán-Torné M, et al. Miopatía y neuropatía inducida por cloroquina: tetraparesia progresiva con arreflexia que simula una polirradiculoneuropatía. A propósito de dos casos. Rev Neurol. 2003 Mar:36(6):523-6. https://doi.org/10.33588/rn.3606.2002407

20. Fodale V, Praticò C, Girlanda P, Baradello A, Lucanto T, Rodolico C, et al. Acute motor axonal polyneuropathy after a cisatracurium infusion and concomitant corticosteroid therapy. Br J Anaesth. 2004 Feb;92(2):289-93. https://doi.org/10.1093/bja/aeh040

21. Thomas RJ. Neurotoxicity of antibacterial therapy. South Med J. 1994 Sep;87(9):869-74. https://doi.org/10.1097/00007611-199409000-00001

22. Sugiura F, Kojima T, Oguchi T, Urata S, Yuzawa Y, Sakakibara A, Hayashi H, Nishimoto N, Ishiguro N. A case of peripheral neuropathy and skin ulcer in a patient with rheumatoid arthritis after a single infusion of tocilizumab. Mod Rheumatol. 2009;19(2):199-203. https:// doi.org/10.1007/s10165-008-0132-2
23. Zorowitz RD. ICU-acquired weakness: a rehabilitation perspective of diagnosis, treatment, and functional management. Brust. 2016 Oct;150(4):966-971. https://doi. org/10.1016/j.chest.2016.06.006

24. Ghasemiyeh P, Borhani-Haghighi A, Karimzadeh I, MohammadiSamani S, Vazin A, Safari A, Qureshi Al. Major Neurologic Adverse Drug Reactions, Potential Drug-Drug Interactions and Pharmacokinetic Aspects of Drugs Used in COVID-19 Patients with Stroke: A Narrative Review. Ther Clin Risk Manag. 2020 Jun 30;16:595-605. https://doi.org/10.2147/TCRM.S259152

25. Rifino N, Censori B, Agazzi E, Alimonti D, Bonito V, Camera G, et al. Neurologic manifestations in 1760 COVID-19 patients admitted to Papa Giovanni XXIII Hospital, Bergamo, Italy. J Neurol. 2020 Oct:1-8. https://doi.org/10.1007/s00415-020-10251-5

26. Filosto M, Cotti Piccinelli S, Gazzina S, Foresti C, Frigeni B, Servalli MC, et al. Guillain-Barré syndrome and COVID-19: an observational multicentre study from two Italian hotspot regions. J Neurol Neurosurg Psychiatry 2020 Nov:jnnp-2020-324837. https://doi. org/10.1136/jnnp-2020-324837

27. Malik GR, Wolfe AR, Soriano R, Rydberg L, Wolfe LF, Deshmukh $S$, et al. Injury-prone: peripheral nerve injuries associated with prone positioning for COVID-19-related acute respiratory distress syndrome. Br J Anaesth. 2020 Dec;125(6):e478-e80. https://doi. org/10.1016/j.bja.2020.08.045 